\title{
Factors influencing phagocytosis of malaria parasites: the story so far
}

\author{
Caroline Lin Lin Chua ${ }^{1 *}$, Ida May Jen $\mathrm{Ng}^{1}$, Bryan Ju Min Yap ${ }^{1}$ and Andrew Teo ${ }^{2,3^{*}}$ (])
}

\begin{abstract}
There are seven known species of Plasmodium spp. that can infect humans. The human host can mount a complex network of immunological responses to fight infection and one of these immune functions is phagocytosis. Effective and timely phagocytosis of parasites, accompanied by the activation of a regulated inflammatory response, is beneficial for parasite clearance. Functional studies have identified specific opsonins, particularly antibodies and distinct phagocyte sub-populations that are associated with clinical protection against malaria. In addition, cellular and molecular studies have enhanced the understanding of the immunological pathways and outcomes following phagocytosis of malaria parasites. In this review, an integrated view of the factors that can affect phagocytosis of infected erythrocytes and parasite components, the immunological consequences and their association with clinical protection against Plasmodium spp. infection is provided. Several red blood cell disorders and co-infections, and drugs that can influence phagocytic capability during malaria are also discussed. It is hoped that an enhanced understanding of this immunological process can benefit the design of new therapeutics and vaccines to combat this infectious disease.
\end{abstract}

Keywords: Phagocytosis, Opsonic, Non-opsonic, Monocytes, Macrophages, Neutrophils, Antibody

\section{Background}

Phagocytosis is a process that involves cellular uptake of particles to mediate the clearance of apoptotic cells and invading micro-organisms. Professional phagocytes such as monocytes, macrophages and neutrophils can be activated to efficiently execute this immune function. Based on the mechanisms of phagocytic target recognition, phagocytosis can be categorized into either opsonic or non-opsonic (as reviewed by Uribe-Querol and Rosales [1]). Opsonic phagocytosis involves the coating of antigens with host proteins (opsonins) such as $\mathrm{C} 3 \mathrm{~b}$ or $\mathrm{C} 4 \mathrm{~b}$ complement fragments, antibodies and collectins, followed by binding of these complexes to phagocytic

\footnotetext{
*Correspondence: linlin.chua@taylors.edu.my; andrewcc.teo@ntu.edu.sg ${ }^{1}$ School of Biosciences, Taylor's University, Subang Jaya, Selangor, Malaysia

${ }^{2}$ Lee Kong Chian School of Medicine, Nanyang Technological University, Singapore, Singapore

Full list of author information is available at the end of the article
}

receptors on immune cells to promote internalization. In non-opsonic phagocytosis, phagocytic targets bind directly to surface receptors such as CD36, toll-like receptors (TLRs) and complement receptor 3 to induce uptake. These receptors recognize pathogen-associated molecular patterns of the microbes, which are molecules that are exclusively expressed by the microbes but not by host cells [2].

Using in vitro models, it was demonstrated that both opsonic and non-opsonic phagocytosis of Plasmodium spp. can be carried out by phagocytes, particularly monocytes and macrophages [3-5]. However, much less understood are the mechanisms that can promote in vivo activation of phagocytes leading to phagocytosis and the downstream phagocytic pathways in patients with malaria. While the phagocytosis of Plasmodium-infected erythrocytes (IEs) is commonly observed in vitro, evidence of phagocytosis in vivo is mainly characterized by the presence of haemozoin within phagocytes [6-8]. Haemozoin is the end product of haemoglobin digestion original author(s) and the source, provide a link to the Creative Commons licence, and indicate if changes were made. The images or other third party material in this article are included in the article's Creative Commons licence, unless indicated otherwise in a credit line to the material. If material is not included in the article's Creative Commons licence and your intended use is not permitted by statutory regulation or exceeds the permitted use, you will need to obtain permission directly from the copyright holder. To view a copy of this licence, visit http://creativecommons.org/licenses/by/4.0/. The Creative Commons Public Domain Dedication waiver (http://creativeco mmons.org/publicdomain/zero/1.0/) applies to the data made available in this article, unless otherwise stated in a credit line to the data. 
by parasites and it is well known for its immunomodulatory activities, including the ability to inhibit further phagocytosis of IEs by macrophages that have previously ingested haemozoin [9]. In contrast, little is known about the mechanisms involved in the uptake of different parasite stages such as sporozoites, merozoites, schizonts and gametocytes, and the downstream molecular consequences. In addition, there are many populations and sub-populations of phagocytes, but their relative importance in the phagocytosis of parasites during malaria is not well studied.

In this review, current knowledge on factors that may enhance or inhibit phagocytosis of Plasmodium spp. and their association with clinical outcomes are reviewed. Additionally, the distinct signalling pathways that are activated following phagocytosis, which may in turn influence the inflammatory and clinical outcomes, are also discussed [10-12]. Plasmodium falciparum is the most deadly and prevalent species in Africa, where malaria burden is also the highest, hence the majority of discussions are focussed on this species, unless specified otherwise. To conclude, several key pathways that can modulate phagocytic function of phagocytes and some important questions for future research are proposed. A better understanding of these molecular and cellular interactions can benefit the design of vaccines and adjunct interventions that enhance anti-parasitic responses in malaria.

\section{Plasmodium spp.: the encounter with phagocytes in infected human host}

Throughout the life cycle of Plasmodium spp., the parasites may encounter different populations of phagocytes in the infected human host. In the initial stage of infection, parasites are injected into the host in the form of sporozoites by Anopheles mosquitoes, and the sporozoites then travel to the liver. After replication in the liver cells, they develop into merozoites, which are released into the blood circulation to invade host erythrocytes. Subsequently, the parasites may develop into either gametocytes or the immature ring-stage trophozoites, followed by mature trophozoites, schizonts and merozoites. Sporozoites within the liver encounter liver macrophages, known as Kupffer cells, whereas the bloodstages of parasites may encounter circulating host monocytes and neutrophils. Mature trophozoites within IEs can be circulated into organs, such as the brain, spleen, placenta, and lung, and sequester within these organs as part of an immune evasion strategy [13]. At this stage, they will encounter tissue macrophages and other circulating phagocytes that have been recruited in response to the local infection [14].
While many studies have shown that professional phagocytes can phagocytize the asexual stages of the parasites $[3,5,15]$, there are contrasting data on the ability of phagocytes to phagocytize gametocytes, the sexual stage parasites. Gametocytes undergo five stages of development from stage I to stage V; early stage gametocytes can be found in the bone marrow, while late stage $\mathrm{V}$ gametocytes can be found in peripheral blood [16]. In the absence of opsonins, human monocytes and macrophages were shown to phagocytize the early stage I and II gametocytes, while mouse bone marrow-derived macrophages were reported to phagocytize early and mature stages of gametocytes; both involved in vitro studies [17, 18]. In contrast, THP-1 macrophages did not phagocytize live, unopsonized and intra-erythrocytic mature stage $\mathrm{V}$ gametocytes [19]. Gametocytes were previously detected in the extracellular environment within the bone marrow, hence they were proposed to be resistant to phagocytosis in vivo [20]. The use of different phagocyte models that may have different expression levels of phagocytic receptors such as CD36 can potentially account for these discordant findings; nonetheless, more studies are required to ascertain this.

In this review, the focus will be on the phagocytosis of asexual stage of the parasites, given that a majority of the data on phagocytosis are based on parasites at this stage. There are many factors that may determine if malaria parasites are phagocytized, including the presence and types of opsonins generated in Plasmodiuminfected hosts, the phenotypes and activation states of host phagocytes, the expression levels of phagocytic cell receptors, and the mechanisms of phagocytosis, whether opsonic or non-opsonic [5, 21,22]. These are discussed in more detail in subsequent sections.

\section{Factors that influence phagocytosis during Plasmodium spp. infection} Opsonizing antibodies: isotypes and specificities Antibodies targeting different stages of the parasite's life cycle have various functions during infection, which include neutralization, antibody-dependent cell inhibition and opsonization. However, to act as an opsonin and promote effective phagocytosis, the antibodies must be of particular isotypes, subclasses and specificities. Using in vitro assays, non-cytophilic antibodies such as IgG4 and IgM were reported to decrease opsonic phagocytosis of sporozoite circumsporozoite protein (CSP) and IEs, respectively $[23,24]$. On the other hand, protective immunity in malaria was mainly associated with IgG1 and IgG3 subclasses (reviewed in [9]). These two antibodies are cytophilic in nature, where they can bind with strong avidity and affinity to antigens via their Fab region, 
and to immune cells expressing Fc receptors via their Fc region.

The opsonizing function of antibodies and the levels of opsonizing antibodies in malaria patients were mainly studied using in vitro phagocytosis assays, which often involve the use of infected-patient sera, cultured parasites and phagocytes. Undifferentiated and differentiated THP-1 monocytic cells are commonly used as the phagocytes in these assays due to convenience in maintaining cell culture, although there are limitations, such as differential expression of phagocytic receptors between these cells and actual circulating phagocytes, which can result in different phagocytic capacity [25]. Antibodies that can specifically induce the phagocytosis of parasites in vitro, referred to as 'opsonizing antibodies' in this review, can be quantified from phagocytosis assays and their correlation with protection can be investigated.

Opsonizing antibodies targeting different stages in the asexual life cycle of the parasites have been associated with protection. For example, opsonizing antibodies that target merozoites were associated with protection against clinical malaria and high parasitaemia $[4,26]$. In adult volunteers who received the RTS-S vaccine, high levels of opsonizing antibodies targeting CSP were induced and these were associated with protection against clinical malaria [27, 28]. Similarly, infected children with higher level of opsonizing antibodies against IEs were less likely to develop severe malaria [29], while high levels of opsonizing antibodies against IEs in pregnant women have been associated with protection from severe malaria and maternal anaemia, suggesting their importance in preventing disease progression [30]. Despite these evidences of protection conferred by opsonizing antibodies, it is noteworthy that these antibodies can also participate in other anti-parasitic functions, such as antibodydependent cell cytotoxicity and antibody-dependent cellular inhibition [31, 32]. Hence, the protection associated with antibody levels may or may not be solely attributed to their ability to increase phagocytosis in vivo, and different antibody functional assays need to be carried out to obtain a better understanding of mechanisms mediating protection.

Previous studies have identified various antigenic targets of naturally acquired opsonizing antibodies produced during $P$. falciparum infection, which can be useful in vaccine design. Specific proteins on the merozoites such as merozoite surface proteins (MSP) 2 and 3, MSP-Duffy binding-like proteins 1 and 2, and glutamate-rich protein have been identified as targets of these opsonizing antibodies [33-35]. Plasmodium falciparum erythrocyte membrane protein 1 (PfEMP1) expressed on the surface of IEs is also a major target of opsonizing antibodies [36], where the antibodies have been shown to recognize DBL2, DBL3, and DBL5e domains of VAR2CSA, which is a member of PfEMP1 protein family [37]. Together, these observations suggest that specific antibodies are required to recognize unique antigens on the parasites for opsonic phagocytosis to take place.

\section{Heterogeneity in host phagocyte subpopulations: who is the big eater? \\ Monocytes: the circulating phagocytes \\ Monocyte sub-set}

Apart from availability of opsonins, phagocytosis of parasites is also dependent on the recruitment of host phagocyte populations, which are often heterogeneous and comprise different sub-populations with distinct phagocytic potentials. Human monocytes can be classified into three major sub-sets based on CD14 and CD16 surface marker expression (Fig. 1). In the circulation of a healthy adult, approximately $90 \%$ of total monocytes are classical monocytes (also described as $\mathrm{CD} 14^{\text {bright }} \mathrm{CD} 16^{-}$), while the remaining $10 \%$ are $\mathrm{CD} 16^{+}$monocytes. The latter sub-set can be further classified into either intermediate/ inflammatory monocytes $\left(\mathrm{CD} 14^{\text {bright }} \mathrm{CD} 16^{+}\right)$or nonclassical monocytes $\left(\mathrm{CD} 14^{\mathrm{dim}} \mathrm{CD} 16^{+}\right)$, and these can be expanded during infection and inflammation. Previous studies have reported the expansion of these monocyte sub-sets in patients with malaria [10,38-40].

\section{Monocyte sub-sets and their phagocytic function}

Comparing across different monocyte sub-sets, the intermediate/inflammatory monocytes were reported to be most efficient in the opsonic phagocytosis of IEs in a previous study [5] (Table 1). In the study, the authors used monocytes from malaria-naive individuals and challenged them with antibody-opsonized IEs in vitro; they also reported that this phagocytosis pathway requires the participation of complement and CD16, which is also known as FcyRIII that binds efficiently to IgG1 and IgG3 antibodies [41]. Using blood samples from Kenyan children with acute malaria, their intermediate/inflammatory and non-classical monocytes showed significantly higher opsonic phagocytosis of IEs compared to classical monocytes [10]. Interestingly, the intermediate/inflammatory monocytes from Plasmodium vivax-infected patients also have the highest phagocytic potential when challenged with $P$. vivax-infected reticulocytes [42]; however, not much is known about monocyte sub-sets in other human Plasmodium spp. infections.

For non-opsonic phagocytosis, intermediate/inflammatory and non-classical monocytes from $P$. falciparum-infected children were shown in vitro to be more efficient in the uptake of IEs compared to classical monocytes, with more prominent effect observed 6 weeks after receiving artemether-lumefantrine 


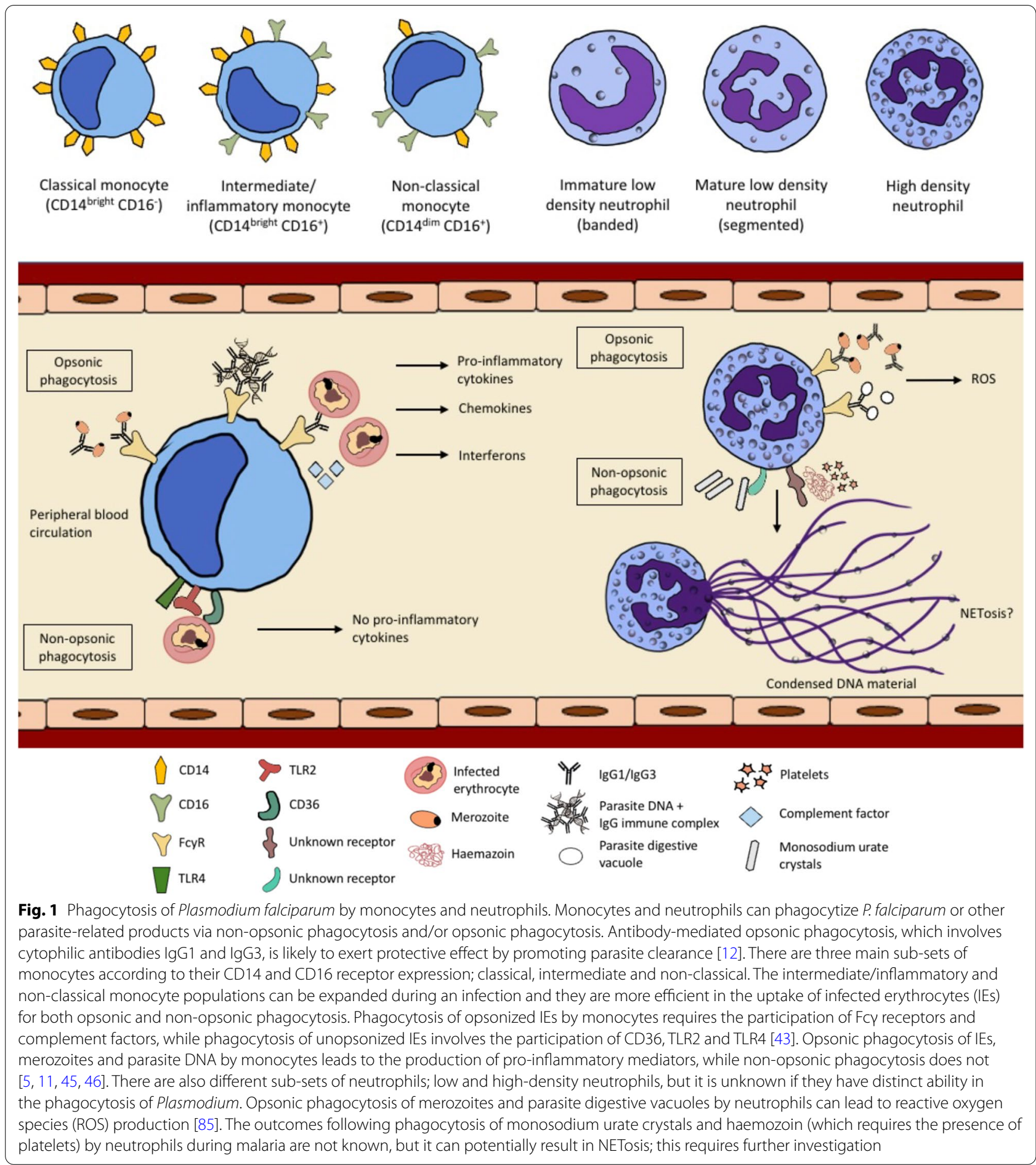

treatment [10]. Importantly, this activity was highest in the intermediate/inflammatory monocytes, which have higher expression of CD36, TLR 2 and TLR4 [10]. High levels of the aforementioned receptors potentially account for their higher phagocytic activities, given that TLR stimulation was previously reported to enhance CD36-mediated non-opsonic phagocytosis [43].

To date, only a few studies investigated the relationship between each monocyte sub-set, their phagocytosis potential and association with protection during Plasmodium spp. infection. Increased levels of the highly 
Table 1 Different sub-populations of phagocytes and their phagocytic ability in malaria

\begin{tabular}{|c|c|c|c|c|c|}
\hline \multirow[t]{2}{*}{ Phagocyte population } & \multirow[t]{2}{*}{ Surface marker expression } & \multirow[t]{2}{*}{ Origin } & \multicolumn{2}{|l|}{ Phagocytic ability } & \multirow[t]{2}{*}{ References } \\
\hline & & & Parasite species & Phagocytic ability & \\
\hline \multicolumn{6}{|l|}{ Monocytes } \\
\hline Classical monocytes & $\mathrm{CD} 14^{\text {bright }} \mathrm{CD} 16^{-}$ & \multirow[t]{3}{*}{ Human } & P. falciparum IEs & \multirow{3}{*}{$\begin{array}{l}\text { Intermediate/inflammatory > non- } \\
\text { classical > classical }\end{array}$} & \multirow[t]{3}{*}[5,10]{} \\
\hline $\begin{array}{l}\text { Intermediate/inflamma- } \\
\text { tory monocytes }\end{array}$ & $\mathrm{CD} 14^{\text {bright }} \mathrm{CD} 16^{+}$ & & & & \\
\hline Non-classical monocytes & CD14 ${ }^{\operatorname{dim}} \mathrm{CD} 16^{+}$ & & & & \\
\hline \multicolumn{6}{|c|}{ Macrophages } \\
\hline \multirow[t]{2}{*}{ Splenic macrophages } & $\mathrm{CD} 11 \mathrm{~b}^{\text {high }} \mathrm{CD} 14^{+} \mathrm{F} 4 / 80^{+} \mathrm{TCR}^{+}$ & Mouse & P. berghei IEs & $\begin{array}{l}\text { Higher phagocytic potential com- } \\
\text { pared to TCR }{ }^{-} \text {macrophages }\end{array}$ & [53] \\
\hline & CD11b+Tim3 ${ }^{+}$ & Mouse & P. berghei IEs & $\begin{array}{l}\text { Reduced phagocytic ability due to } \\
\text { Tim3 expression }\end{array}$ & [55] \\
\hline \multicolumn{6}{|l|}{ Neutrophils } \\
\hline TCR $\beta+$ neutrophils & CD11 $b^{+}$Ly6G ${ }^{+} T C R \beta+$ & Mouse & P. berghei IEs & $\begin{array}{l}\text { Higher phagocytic potential com- } \\
\text { pared to TCRß }{ }^{-} \text {neutrophils }\end{array}$ & [79] \\
\hline Low density neutrophils & $\mathrm{CD}_{6} \mathrm{~b}^{+} \mathrm{CD} 16^{+} \mathrm{CD} 11 \mathrm{~b}^{+} \mathrm{CD} 15^{+}$ & Human & P. vivax-infected reticulocytes & $\begin{array}{l}\text { Comparable phagocytic potential } \\
\text { to high density neutrophils from } \\
\text { malaria patients, higher phago- } \\
\text { cytosis ability compared to high } \\
\text { density neutrophils from healthy } \\
\text { donors }\end{array}$ & [76] \\
\hline
\end{tabular}

phagocytic intermediate/inflammatory monocytes did not appear to be associated with protection as they have been reported in children with severe anaemia, suggesting that increased phagocytosis may instead contribute to pathology by accelerating erythrocyte destruction [39]. In contrast, in a recent study involving Beninese young children, lower levels of non-classical monocytes were found in patients who died from malaria and these reduced levels were associated with increased disease severity, characterized by development of severe anaemia and cerebral malaria [44]. However, whether or not this protection from mortality and disease severity is attributed to the monocytes' high phagocytosis ability and their inflammatory responses remains to be determined.

\section{Monocyte activation following phagocytosis}

The uptake of $P$. falciparum and its associated proteins by monocytes via distinct phagocytosis pathways can lead to different consequences. Non-opsonic phagocytosis of IEs by human peripheral monocytes via CD36 receptor does not induce tumour necrosis factor (TNF) production [45]. In contrast, opsonic phagocytosis appears to be associated with the activation of innate immune responses. Stimulation of monocytes from malarianaïve individuals with antibody-opsonized IEs and purified parasite DNA-containing immune complexes can activate signalling pathways that lead to the production of pro-inflammatory cytokines, TNF and IL-1 $\beta[5,11$, 46]. Using $P$. vivax-patient samples, the intermediate/ inflammatory monocytes have been identified as the main producers of pro-inflammatory cytokines upon stimulation with immune complexes [11]. Besides being associated with specific antibodies, parasite DNA can also be bound to haemozoin or be packaged in extracellular vesicles during parasite ring stage, prior to being phagocytized by monocytes $[47,48]$. These extracellular vesicles may contain both genomic DNA and small RNA, and upon release into host cell cytosol, they can activate 'stimulator of interferon genes' (STING) [48]. STING is a cytosolic DNA sensor and was shown to induce the production of type I interferons and chemokines by THP-1 monocytes stimulated with parasite extracellular vesicles [48].

\section{Macrophages: the tissue phagocytes Macrophage sub-sets and their phagocytosis function during malaria}

Macrophages exist in a continuum of activation states and they are commonly classified into M1 and M2 macrophages. M1 macrophages mainly secrete proinflammatory cytokines such as TNF, IL-1 and IL-6, while M2 macrophages can produce high levels of antiinflammatory cytokines such as IL-10 and TGF- $\beta$ [49]. There are also other alternative sub-populations such as CD169 ${ }^{+}$, $\mathrm{T}$ cell receptor $(\mathrm{TCR})^{+}$and tumour-associated macrophages [50], but these are less well understood compared to the M1 and M2 paradigm. In lung tissues of patients who died from P. falciparum infection with pulmonary oedema, increased numbers of lung macrophages exhibiting $\mathrm{M} 1$ phenotype $\left(\mathrm{CD}^{+} 8^{+} \mathrm{CD} 40^{+}\right)$ 
have been reported [51], suggesting their role mediating lung pathology. In other cases of severe malaria, such as cerebral and placental malaria, high levels of proinflammatory cytokines and growth factors, such as TNF, interferon (IFN) $-\gamma$ and granulocyte/macrophage colony stimulating factor (GM-CSF) could potentially polarize tissue macrophages to $\mathrm{M} 1$ phenotype; this remains to be proven in future studies.

Due to the inaccessibility to human macrophages in different organs, most of the understanding of parasite-macrophage interactions are based on animal models. In a transgenic BALB/c mouse model where mice were depleted of CD169 using diphtheria toxin and infected with Plasmodium berghei, $\mathrm{CD} 169^{+}$tissue-resident macrophages that are usually found in the spleen, lymph nodes and liver sinusoids were reported to be crucial in limiting parasite sequestration, which otherwise can lead to systemic inflammation and multiple organ damage [52]. In another study using C57BL/6 mice, it was reported that a novel population of $\mathrm{CD} 11 \mathrm{~b}^{\text {high }} \mathrm{CD} 14^{+} \mathrm{F} 4 / 80^{+}$macrophages that express combinatorial TCR $\beta$ receptor can be expanded during $P$. berghei infection [53]. These cells are found primarily in the brain and spleen during $P$. berghei infection and are highly efficient in the phagocytosis of IEs, a function attributed to the expression of TCR $\beta$ receptor [53]. In humans, a small proportion of monocytes (approximately $5 \%$ ) also express TCR $\alpha \beta$ [54] but its role in phagocytosis of parasites has yet to be determined. It is also unknown if TCR activation may play a direct role in promoting phagocytosis by macrophages expressing this receptor; while TCRs are required for antigen recognition by $\mathrm{T}$ cells and $\mathrm{T}$ cell activation, the effect of activating these receptors in macrophages is still unknown.

The expression of T-cell immunoglobulin and mucindomain-containing molecule 3 (Tim-3) is reduced in monocytes from patients infected with $P$. falciparum and in splenic macrophages of $P$. berghei-infected mice [55]. Tim-3 is known to induce M2 macrophage polarization, hence its decreased expression may favour M1 macrophage activation to promote early parasite clearance; this remains to be proven. Although Tim-3 has been implicated in the clearance of apoptotic cells by binding to phosphatidylserine, it appears to inhibit the ability of $\mathrm{CD} 11 \mathrm{~b}^{+}$mouse splenic macrophages to phagocytized $P$. berghei-infected cells [55].

Macrophages reside in tissues, therefore they usually phagocytize mature-stage IEs (Fig. 2). The exception is for Kupffer cells, which serve as portal of entry for sporozoites to invade hepatocytes. These liver macrophages

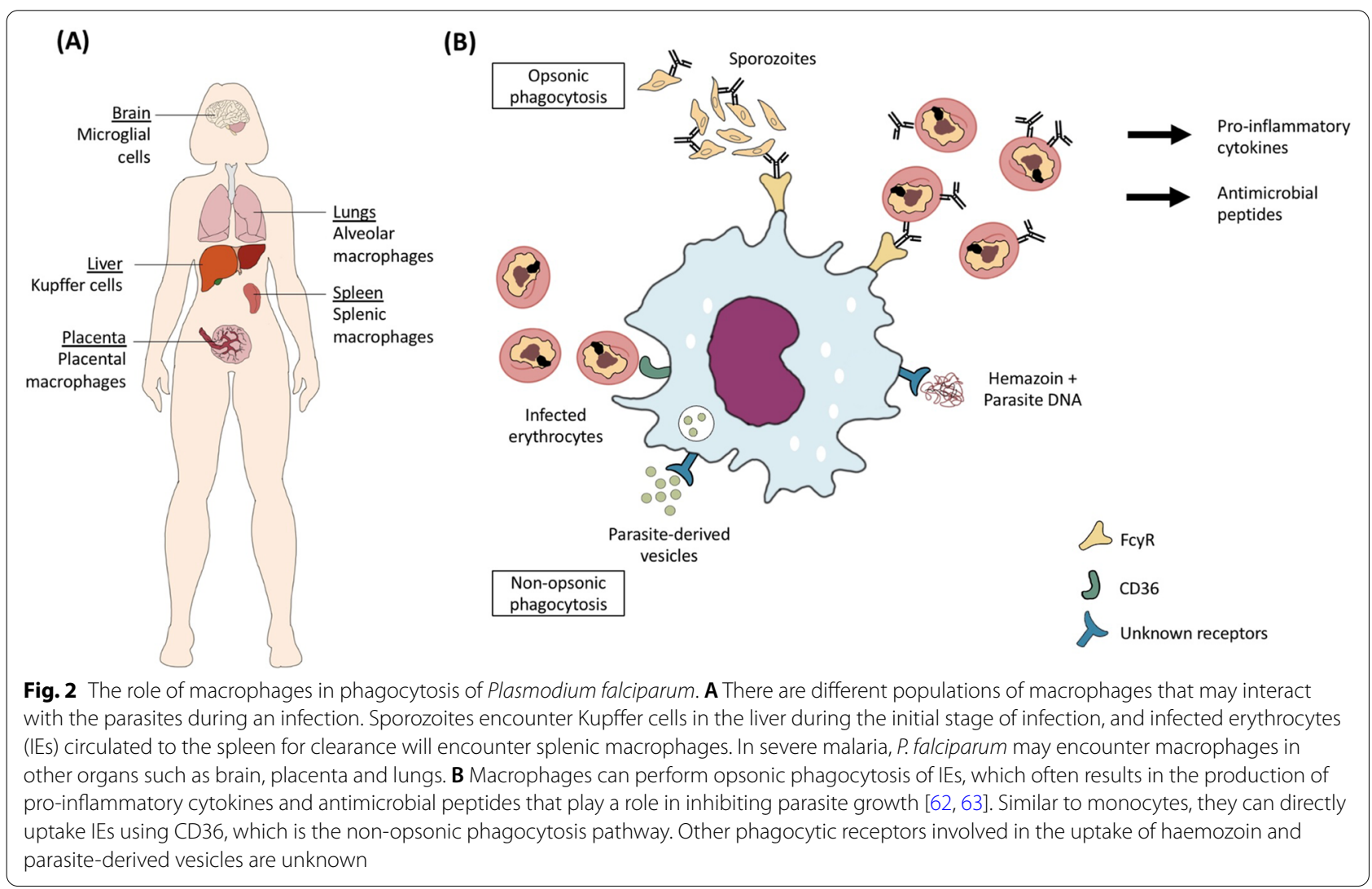


can phagocytize antibody-opsonized sporozoites, subsequently prevent the development of a blood-stage infection. Previous studies with different rodent models suggest that there are specific Kupffer cell populations that preferentially support either a protective or pathological role during sporozoites infection. One study reported that Kupffer cells that express CD68 support the entry of sporozoites to cause infection [56], while another showed that Kupffer cells that express triggering receptor expressed on myeloid cells 2 (TREM2) are able to reduce hepatocyte infection [57]. TREM2 is known to be an important phagocytic receptor that mediates the uptake of apoptotic cells, bacteria and lipids, as well as triggering pro-inflammatory pathways [58]. More studies are needed to elucidate its role during Plasmodium spp. infection.

Although there are interesting findings from rodent models, it is unknown whether these are fully translatable to human infections as there may be phenotypic and potentially functional differences between rodent and human macrophages. Within the spleen, red pulp macrophages, which are the most abundant macrophage population in the spleen, are involved in the clearance of aberrant and aged erythrocytes [59]. Rodent red pulp macrophages, characterized as $\mathrm{F} 4 / 80^{\mathrm{hi}} \mathrm{Mac}-1^{\text {low }}$ population, showed strong phagocytic activity for serumopsonized zymosan (a structural component of yeast cell wall), suggesting that they are efficient at mediating opsonic phagocytosis [60]. On the other hand, human splenic red pulp macrophages are characterized as CD163 ${ }^{\text {high }} \mathrm{CD} 14^{\text {low }} \mathrm{CD} 11 b^{-}$Fc $\mathrm{RIIb}^{-}$population [61], and they also express other Fc receptors such as FcyRIIa and FcyRIIIa [61], but their ability to phagocytize IEs is not known. It is worth noting that for most tissue macrophages especially from humans, their immunological phenotypes and functions are not well understood. Hence, to enhance the understanding of the phagocytosis potential of these cells during Plasmodium spp. infection, it is useful to develop different humanized macrophage models or cell isolation protocols that allow distinct cell populations to be isolated wherever possible.

\section{Macrophage activation following phagocytosis}

Similar to monocyte activation, one of the main downstream consequences following opsonic phagocytosis by macrophages is the production of pro-inflammatory mediators. Using monocyte-derived macrophages from malaria-naïve individuals, it was reported that phagocytosis of antibody-opsonized IEs resulted in the secretion of TNF and IL-1 $\beta$, with the latter occurring due to the activation of inflammasome following $\mathrm{Fc} \gamma \mathrm{R}$ engagement [62]. The phagocytosis of IEs by monocyte-derived macrophages also led to the up-regulation of $\beta$-defensin 130
(DEFB130), which is an antimicrobial peptide that can inhibit parasite growth in vitro [63]. In a rodent model, it was shown that haemozoin coupled to parasite DNA can be phagocytized by macrophages into phagolysosomes, with the haemozoin subsequently dissociating from the DNA and induce phagolysosomal destabilization [64]. This allows the nucleic acid to be released into the cytosol and bind to intracellular sensors such as TLR9 to initiate an inflammatory response, characterized by proinflammatory cytokine production [65].

In mouse models of experimental cerebral malaria (ECM), phagocytosis of parasite-derived vesicles by astrocytes and IEs by brain macrophages (microglia cells) led to increased production of inflammatory mediators such as CXCL-10 and high levels of CXCL-10 predicted mortality in ECM $[66,67]$. To further corroborate the pathological role of CXCL-10 in malaria, elevated levels of this molecule were associated with increased risk of fatal cerebral malaria in children [68]. In a recent study, $\mathrm{CD} 14^{+}$monocytes were identified as the main producers of CXCL-10 when challenged with $P$. falciparum, but the sub-sets that were involved and the association between CXCL-10 levels and parasite burden in humans remain unknown [69]. In addition, using an in vitro model of human blood monocyte-derived microglia cells, the uptake of IE-derived extracellular vesicles was shown to cause down-regulation of IL-6 and IL-10 gene expression [70]. When mouse macrophages were challenged with these vesicles, they produced TNF and up-regulated their CD40 expression [71]. Extracellular vesicles appear to be important in mediating cell-cell communication and immune cell activation, hence further research is needed to understand the mechanisms and receptors involved in the uptake of these vesicles.

\section{Neutrophils: the circulating and most abundant phagocytes \\ Neutrophil sub-sets}

Neutrophils are the most abundant leukocytes in circulation and they express high levels of Fcy receptors. Of the three Fc $\gamma$ Rs, they express highest levels of FcyRIIIB [72]. Neutrophils have been shown to phagocytize antibodyopsonized merozoites, haemozoin and IEs, however, the association between neutrophil phagocytosis and protection against malaria is not well understood. Similar to monocytes and macrophages, heterogeneity within the neutrophil population has also been recognized [73]. They can switch their phenotype in response to stimuli such as GM-CSF and can be primed to enhance certain immune functions such as phagocytosis [74]. Neutrophils exist in different maturation states within peripheral blood, including immature (with band-shaped nuclei), mature (with segmented nuclei) and aged (with 
hypersegmented nuclei) neutrophils. Immature neutrophils are usually present in the bone marrow, but they may be detected in the peripheral blood during state of infection and inflammation, including malaria $[75,76]$. Mature neutrophils are terminally differentiated in the bone marrow before being released into the circulation, while aged neutrophils are eventually cleared by macrophages in the liver and spleen [77]. Although these neutrophil populations appear different in their phenotypes, it is unknown if they play distinct or overlapping roles in malaria.

\section{Neutrophil sub-sets and their phagocytosis function}

Circulating neutrophils appear to be a heterogeneous population that exhibit either high and/or low phagocytic potentials; however, it remains challenging to characterize and differentiate these cells in humans [78]. A specific sub-population of mouse $\mathrm{TCR} \beta^{+}$neutrophils were reported to be highly efficient in in vitro phagocytosis of $P$. berghei-IEs, with fourfold greater efficiency compared to TCR $\beta^{-}$neutrophils [79]. In the human population, it was reported that approximately 5 to $8 \%$ of human neutrophils express this receptor [80]. However, it is unknown if the highly phagocytic neutrophil subset is associated with protection from clinical and severe malaria.

Neutrophils have been further classified into high- and low-density neutrophils, with the latter being found in the peripheral blood of cancer patients and those with HIV infection [83]. While low-density neutrophils may comprise immature neutrophils and activated mature neutrophils, these sub-populations remain poorly defined, both phenotypically and functionally [83]. Increased proportions of low-density neutrophils/granulocytes have been reported in patients with $P$. vivax infection, where the authors suggested that these cells were comprised of activated degranulated neutrophils [76]. Although the low-density neutrophils exhibited decreased ability in phagocytizing bacterial cells [81], they were reported to have high ability in the uptake of $P$. vivax-infected reticulocytes [76]. In another study, neutrophils isolated from $P$. vivax-infected patients also showed higher phagocytosis ability compared to neutrophils isolated from healthy donors [82]. The authors used opsonized zymosan as phagocytic targets, hence Plasmodium spp. infection may have up-regulated $\mathrm{Fc} \gamma \mathrm{R}$ expression on neutrophils to enhance opsonic phagocytosis.

\section{Neutrophil activation following phagocytosis}

Neutrophils can generate reactive oxygen species (ROS) when activated, and these highly toxic molecules can kill parasites by causing oxidative damage. ROS levels have been shown to be associated with protection against fatal cerebral malaria and clinical malaria episodes [83, 84]. Interestingly, ROS production was induced when neutrophils were stimulated with opsonized merozoites and parasite digestive vacuoles, but was undetectable when opsonized IEs were used as targets [85]. This suggests that the induction of ROS may depend on specific parasite antigens, and previous studies demonstrated high levels of antibodies targeting MSP-1, MSP-4 and MSP-5 to be correlated with ROS production $[83,86]$.

Uptake of unopsonized IEs by neutrophils in vitro resulted in increased pro-inflammatory responses, characterized by the up-regulation of mitogen-activated protein kinase, interleukin and interferon-gamma signalling pathways [87]. Interestingly, this is in contrast to non-opsonic phagocytosis of parasites by monocytes/ macrophages, which does not induce production of proinflammatory mediators. Future studies investigating the underlying reasons for this difference are needed to better understand the immunomodulatory effect of parasites on phagocytes.

Another function of neutrophils in defence against Plasmodium spp. is neutrophil extracellular traps (NETs) formation via a type of programmed cell death known as NETosis. This process results in the release of neutrophil intracellular content, including decondensed chromatin coupled with granular proteins and histones that can trap pathogens. Monosodium urate crystals and haem are two products released into the blood circulation following IEs rupture and both can cause the release of NETs [88, 89]. Phagocytosis of monosodium urate crystals involves actin cytoskeleton remodelling and this process is required to promote NETosis [90]. However, it is currently unknown if haem similarly needs to be phagocytized to trigger NETosis, or the surface receptor-ligand interaction is sufficient to induce the release of NETs. Although NETs are useful in limiting the proliferation and dissemination of pathogen, they were reported to induce up-regulation of endothelial cytoadhesion receptors, leading to increased parasite sequestration in mice malaria [89]. This can potentially cause vaso-occlusion and increased disease severity observed in severe malaria cases [89].

\section{Parasite haemozoin can stimulate phagocytosis}

When IEs rupture, haemozoin crystals are released and taken up by phagocytes. The phagocytosis of haemozoin by neutrophils was recently reported to be dependent on the presence of platelets and can be inhibited by host fibrinogen [91]. Neutrophils that have phagocytized haemozoin have been associated with severe and poor clinical outcomes in P. falciparum $[8,92]$ and P. vivax infections [76]. Similarly, monocytes that have phagocytized haemozoin have been associated with severe malaria 
in children and low birth weight in placental malaria $[7,93]$. Post-mortem analysis of $P$. falciparum-infected organs often show the presence of haemozoin-laden macrophages, indicating that they are well capable of phagocytosis. However, haemozoin cannot be degraded in the phagocytes and often results in the impairment of phagocyte function, where they do not repeat the phagocytic cycle after ingesting the haemozoin, thus reducing phagocytosis capacity [9].

\section{Specific interaction of parasites with host phagocytes}

Plasmodium spp. can also manipulate its interaction with host phagocytic receptors and the downstream signalling pathways to escape phagocytosis. For example, in Plasmodium yoelii mouse malaria model, the parasites preferentially infect erythrocytes that express high levels of CD47 [94], allowing them to escape phagocytosis by red pulp macrophages in the spleen. CD47 is a self-marker that inhibits phagocytosis by interacting with macrophage signal-regulatory protein alpha, hence decreased CD47 can promote phagocytic clearance. Plasmodium falciparum- and P. vivax-IEs were reported to express higher levels of CD47 compared to uninfected erythrocytes, however, the mechanism of this higher expression is unknown [95]. In addition, the parasites can also evade phagocytosis by acquiring complement regulatory proteins, whose function is to protect host cells against complement-mediated damage. Merozoites and IEs can actively recruit and use host regulatory proteins such as Factor $\mathrm{H}$ and Factor $\mathrm{H}$-like protein to inactivate $\mathrm{C} 3 \mathrm{~b}$ on the surface of IEs, hence prevent complement-mediated phagocytic clearance of the parasites [96, 97].

Another example is the evasion of phagocytosis through antigenic switching by placental-binding IEs. Parasites found in the placenta commonly attach to chondroitin sulfate A and are unable to bind CD36, a macrophage phagocytic receptor, hence they accumulate in the placenta and cause pathologies [98]. This is particularly true in primigravids, who have yet to develop protective antibody immunity. During infection, the expression of complement receptor 1 (CR1) by monocytes/macrophages is down-regulated [99], leading to high levels of immune complexes such as those observed in patients with severe anaemia and cerebral malaria. CR1 binds to immune complexes and causes them to be phagocytized, which otherwise can cause pathologies due to activation of immune responses. Interestingly, IEs also preferentially bind to CR1 expressed by uninfected erythrocytes to form rosettes, which may potentially shield them from phagocyte recognition. A recent study reported that IEs can stimulate monocytes to produce insulin growth factor binding protein 7 , which promotes rosette formation and subsequently inhibits monocyte phagocytosis [100]. Non-rosetting $P$. vivax IEs were also shown to be more likely to be phagocytized by THP-1 macrophages [101]. Lastly, parasites may directly induce apoptosis of phagocytes, as shown in Kupffer cells during rodent malaria [102].

\section{Host inflammatory mediators}

In response to malaria parasites, host immune cells can produce a variety of cytokines that can direct the activation or priming status of phagocytes, hence influence their phagocytic ability. For example, IFN- $\gamma$ is known to enhance opsonic phagocytosis of IEs by increasing the expression of Fc $\gamma$ RI [103], which is beneficial for parasite clearance. Early and high production of IFN- $\gamma$ has been associated with protection against symptomatic malaria [104]. In vitro treatment of human neutrophils with various pro-inflammatory cytokines (IFN- $\gamma$, IL-1 $\beta$, TNF and GM-CSF) was reported to increase phagocytosis of opsonized merozoites [15], while priming with IFN- $\gamma$ enables them to efficiently phagocytize unopsonized IEs [87]. Furthermore, in rodent models, treatment with IFN- $\gamma$ or TNF was reported to enhance the phagocytosis of unopsonized merozoites by peritoneal macrophages, whereas IL-10 treatment was reported to significantly reduce the phagocytosis potential of these macrophages [105]. It remains difficult to determine if the cytokines are contributing to either disease protection or pathology by modulating phagocytosis or through other mechanisms, given that each cytokine may exhibit pleiotropic effects.

\section{Underlying red cell disorders and blood group}

Red cell disorders, such as thalassemia, glucose-6-phosphate dehydrogenase (G6PD) deficiency and sickle cell trait have been associated with protection against severe malaria [106-108]. One of the proposed mechanisms of protection is the increased and early phagocytic clearance of IEs in these individuals. Increased deposition of autologous IgG and complement C3c fragments, as well as membrane-bound hemichromes and aggregate band 3, was found in ring-stage IEs from individuals with sickle trait and beta-thalassemia trait; these promote phagocytosis of ring-stage parasites by human monocytes [109]. Similarly, ring-stage IEs that were deficient in G6PD were also more efficiently phagocytized compared to normal infected erythrocytes due to higher levels of autologous IgG and complement C3 fragments [110]. A recent study reported that sickle cells have a higher expression of terminal mannose, which can be recognized by mannose receptors on macrophages and promote phagocytosis [111]. Interestingly, it was also reported that $P$. falciparum-infected $\mathrm{O}$ erythrocytes were taken up more 
efficiently by human macrophages in vitro and mouse monocytes in vivo compared to infected $\mathrm{A}$ and $\mathrm{B}$ erythrocytes [112], suggesting that this could be one of the mechanisms by which individuals with blood type $\mathrm{O}$ are protected against severe malaria.

\section{Human immunodeficiency virus (HIV) co-infection}

HIV infection is prevalent in many malaria-endemic regions, leading to cases of co-infection. Studies investigating immune responses in these individuals suggest that phagocytosis of IEs may be compromised via several mechanisms. Reduced levels of opsonizing antibody to both placental-binding and non-placental-binding IEs have been associated with HIV infection [113, 114]. In addition, HIV-infected macrophages have reduced capacity to phagocytize IEs and secrete lower quantities of pro-inflammatory cytokines [115]. HIV infection is also associated with reduced expression of $\mathrm{Fc} \gamma \mathrm{Rs}$ on macrophages [116], potentially reducing opsonic phagocytosis of parasites. These studies imply that co-infection with HIV can cause impaired parasite clearance, subsequently leading to adverse malaria outcomes.

\section{Anti-malarials and antibiotics: beyond their anti-microbial functions}

Several in vitro studies showed that anti-malarial drugs and antibiotics administered to Plasmodium spp.infected patients can modulate host immune cell phagocytosis function. An older study reported that IEs treated with anti-malarials, such as chloroquine, quinine, amodiaquine, and mefloquine, can down-regulate IgG opsonization of these cells and prevent phagocytosis [117]. A recent study reported that artemesinin, quinine, primaquine, and pyrimethamine can increase the phagocytosis of synthetic haemozoin by monocytes, while amodiaquine, chloroquine and doxycycline had opposing effect [118]. The development of resistance by the malaria parasites against existing anti-malarials has led to the development of new drug formulations, including use of antibiotics that may have immunomodulatory effects. For example, studies have trialled the use of azithromycin as a potential anti-malarial drug and this antibiotic has been shown to promote phagocytosis of apoptotic cells by alveolar macrophages [119]. Furthermore, many of these drugs have anti-inflammatory properties and more studies need to be done to understand how they may affect phagocytosis of Plasmodium.

\section{Modulation of phagocytosis function}

Knowledge of the molecular interactions between phagocytes and parasites is useful in the design of therapeutics that can modulate their phagocytosis function. To date, three promising immunomodulatory compounds, namely curcumin, rosiglitazone and Vitamin A, have been shown to increase phagocytosis receptor expression and phagocytosis of parasites [120-122]. Inhibitory molecules that target specific immune pathways may also be useful in altering the phagocytic function of phagocytes. For example, PD98059, a MEK (mitogen-activated protein kinase kinase) $1 / 2$ inhibitor, was reported to enhance the clearance of parasites by splenic and liver macrophages and neutrophils by increasing phagocytic receptor expression such as CD36, MARCO and complement receptor $1 / 2$ [123]. Furthermore, the phagocytic process can be regulated by Rab14, a GTPase whose expression was shown to be up-regulated in mouse macrophages after $P$. berghei infection [124]. Rab14, which localizes to early endosomes, can mediate phagosome maturation and internalization of pathogens in murine bone marrow-derived macrophages, which in turn decreases CD36 expression and suppresses phagocytosis $[124,125]$. Future studies are needed to investigate whether human malaria infection affects Rab14 expression and if this has any effect on parasite clearance. If phagocytosis is suppressed, then Rab14 inhibitor proteins can potentially improve phagocytosis and promote parasite clearance.

Given the pathological role of M1 and M2 macrophages in various inflammatory diseases, drugs and nanoparticles specifically targeting the function of these immune cells have been designed as treatment options [126]. The therapy aims to alter the polarization status, recruitment and function of macrophages, including cytokine production and phagocytosis. Many natural compounds also have the ability to promote or alter the polarization status of macrophages but so far, none of these has been tested in the malarial setting [127]. Host defence peptides such as cathelicidin are also potential immunomodulatory molecules. They can be administered as synthetic peptides or by inducing their production through the consumption of Vitamin D or butyrate [128, 129]. One of these peptides, LL-37, has been reported to up-regulate phagocytosis levels by increasing the expression of $\mathrm{Fc} \gamma$ receptors $I$ and II, in addition to acting as opsonins for gram positive and negative bacteria $[130,131]$. However, the role of these antimicrobial peptides in regulating phagocytosis during Plasmodium-infection has yet to be investigated.

\section{Concluding remarks and future perspectives}

The understanding of factors that contribute to the success of phagocytosis in controlling the malaria parasite is still rather limited; herein, priorities for future research are listed in Table 2. With major advancement in cell-targeted immunomodulatory therapy, enhanced knowledge of phagocyte functions during malaria is 
Table 2 Priorities for future research in understanding phagocytosis during Plasmodium infection

\section{Phagocytes and clinical protection}

Does high phagocytosis potential of specific immune cells or their subpopulations correlate with protection and disease progression?

What parameters can be used to define 'effective phagocytosis' level (level that is sufficient to confer protection against clinical disease)?

Can host genetic variations lead to different expression levels of phagocytic receptors, and will these impact phagocytic potentials of phagocytes, hence leading to different disease susceptibility?

How are the expression of opsonic and non-opsonic phagocytosis receptors regulated during malaria infection and do these expressions correlate with protection/pathology?

\section{Molecular mechanisms of phagocytosis}

Are there specific phagocyte population or subpopulations that are responsible for clearing different stages of the parasites in their asexual life cycle?

Which parasite ligands specifically interact with the phagocytes, leading to immunomodulation of phagocytosis?

What are the other phagocytic receptors involved in non-opsonic phagocytosis of Plasmodium and what are the downstream consequences of this interaction?

What are the roles of host defence peptides in phagocytosis during malaria infection?

\section{Immune activation following phagocytosis}

Are there adverse consequences that may result from increased phagocytosis, such as activation of inflammation that results in endothelial-lining damage and host pathology?

\section{Modulation of phagocytosis}

How do chronic or co-infections, such as HIV, hepatitis or helminth infections, affect the phagocytic function of phagocytes in infected hosts?

Can specific compounds or therapeutics with the potential to increase the rate phagocytosis improve treatment outcomes and/or reduce clinical manifestations of malaria?

Will immunoregulatory therapeutics aimed at dampening immune responses during severe malaria decrease phagocytic capability and thus, reduce the efficiency of parasite clearance?

What are the specific immune evasion strategies employed by Plasmodium parasites to avoid phagocytosis by phagocytes?

likely to be beneficial in the design of new therapeutics. In particular, understanding the role of different subpopulations of phagocytes, whether they contribute to protection or pathology, is critical. For future studies aimed at assessing the role of phagocytosis during Plasmodium infection, it is important to note that besides the availability of opsonins, the presence of the protective phagocyte sub-populations, if they exist, is also of paramount importance.

\section{Abbreviations}

CR1: Complement receptor 1; CSP: Circumsporozoite protein; DEFB130: $\beta$-Defensin 130; ECM: Experimental cerebral malaria; G6PD: Glucose-6-phosphate dehydrogenase; GM-CSF: Granulocyte/macrophage colony stimulating factor; HIV: Human immunodeficiency virus; IEs: Plasmodium-infected erythrocytes; IFN: Interferon; IgG: Immunoglobulin; MSP: Merozoite surface protein; MSPDBL: MSP-Duffy binding-like; NETs: Neutrophil extracellular traps; PfEMP1: Plasmodium falciparum erythrocyte membrane protein 1; ROS: Reactive oxygen species; STING: Stimulator of interferon genes; TCR: T cell receptor; TIM-3: T-cell immunoglobulin and mucin-domain-containing molecule-3; TLR: Toll like receptor; TNF: Tumour necrosis factor; TREM2: Triggering receptor expressed on myeloid cells2.

\section{Acknowledgements}

Not applicable.

\section{Authors' contributions}

All authors contributed substantially to this publication. CLLC and AT conceptualised the research idea, and were the major contributors to the writing and editing of this manuscript. IMJN and BYJM contributed to literature search, writing and figures preparation. All authors read and approved the final manuscript.

\section{Funding}

CLLC received support from Ministry of Education (MOE) Fundamental Research Grant Scheme of Malaysia (FRGS/1/2015/SKK08/Taylor/03/2). BJMY is supported by Taylor's University through its Taylor's Research Scholarship Programme. AT is supported by Nanyang Technological University Research Scholarship Block Fellowship of Singapore and Lee Kong Chian School of Medicine, Nanyang Technological University Singapore Start-Up grant.

\section{Availability of data and materials}

Not applicable.

\section{Declarations}

Ethics approval and consent to participate

Not applicable.

\section{Consent for publication}

Not applicable.

\section{Competing interests}

The authors declare that they have no competing interests.

\section{Author details}

${ }^{1}$ School of Biosciences, Taylor's University, Subang Jaya, Selangor, Malaysia. ${ }^{2}$ Lee Kong Chian School of Medicine, Nanyang Technological University, Singapore, Singapore. ${ }^{3}$ Department of Medicine, The Doherty Institute, University of Melbourne, Victoria, Australia.

Received: 4 March 2021 Accepted: 7 July 2021

Published online: 16 July 2021 


\section{References}

1. Uribe-Querol E, Rosales C. Phagocytosis: our current understanding of a universal biological process. Front Immunol. 2020;11:1066.

2. Moretti J, Blander JM. Insights into phagocytosis-coupled activation of pattern recognition receptors and inflammasomes. Curr Opin Immunol. 2014;26:100-10

3. Ayi K, Patel SN, Serghides L, Smith TG, Kain KC. Nonopsonic phagocytosis of erythrocytes infected with ring-stage Plasmodium falciparum. Infect Immun. 2005:73:2559-63.

4. Osier FHA, Feng G, Boyle MJ, Langer C, Zhou J, Richards JS, et al. Opsonic phagocytosis of Plasmodium falciparum merozoites: mechanism in human immunity and a correlate of protection against malaria. BMC Med. 2014:12:108.

5. Zhou J, Feng G, Beeson J, Hogarth PM, Rogerson SJ, Yan Y, et al. CD14(hi)CD16+ monocytes phagocytose antibody-opsonised Plasmodium falciparum infected erythrocytes more efficiently than other monocyte subsets, and require CD16 and complement to do so. BMC Med. 2015;13:154

6. Teo A, Hasang W, Boeuf P, Rogerson S. A robust phagocytosis assay to evaluate the opsonic activity of antibodies against Plasmodium falciparum-infected erythrocytes. Methods Mol Biol. 2015;1325:145-52.

7. Rogerson SJ, Pollina E, Getachew A, Tadesse E, Lema VM, Molyneux ME. Placental monocyte infiltrates in response to Plasmodium falciparum malaria infection and their association with adverse pregnancy outcomes. Am J Trop Med Hyg. 2003;68:115-9.

8. Chua CLL, Robinson LJ, Baiwog F, Stanisic DI, Hamilton JA, Brown GV, et al. High numbers of circulating pigmented polymorphonuclear neutrophils as a prognostic marker for decreased birth weight during malaria in pregnancy. Int J Parasitol. 2015;45:107-11.

9. Tyberghein A, Deroost K, Schwarzer E, Arese P, Van den Steen PE. Immunopathological effects of malaria pigment or hemozoin and other crystals. BioFactors. 2014;40:59-78.

10. Dobbs KR, Embury P, Vulule J, Odada PS, Rosa BA, Mitreva M, et al. Monocyte dysregulation and systemic inflammation during pediatric falciparum malaria. JCI Insight. 2017:2:e95352.

11. Hirako IC, Gallego-Marin C, Ataide MA, Andrade WA, Gravina H, Rocha $B C$, et al. DNA-containing immunocomplexes promote inflammasome assembly and release of pyrogenic cytokines by CD14+ CD16+ CD64high CD32low inflammatory monocytes from malaria patients. MBio. 2015;6:e01605-15.

12. Teo A, Feng G, Brown GV, Beeson JG, Rogerson SJ. Functional antibodies and protection against blood-stage malaria. Trends Parasitol. 2016;32:887-98

13. Miller LH, Baruch DI, Marsh K, Doumbo OK. The pathogenic basis of malaria. Nature. 2002:415:673-9.

14. Ordi J, Menendez C, Ismail MR, Ventura PJ, Palacín A, Kahigwa E, et al. Placental malaria is associated with cell-mediated inflammatory responses with selective absence of natural killer cells. J Infect Dis. 2001:183:1100-7.

15. Kumaratilake LM, Ferrante A. Opsonization and phagocytosis of Plasmodium falciparum merozoites measured by flow cytometry. Clin Diagn Lab Immunol. 2000;7:9-13.

16. Gardiner DL, Trenholme KR. Plasmodium falciparum gametocytes: playing hide and seek. Ann Transl Med. 2015;3:45.

17. Smith TG, Serghides $L$, Patel $S N$, Febbraio $M$, Silverstein $R L$, Kain $K C$. CD36-mediated nonopsonic phagocytosis of erythrocytes infected with stage I and IIA gametocytes of Plasmodium falciparum. Infect Immun. 2003;71:393-400.

18. Corbett Y, Parapini S, Perego F, Messina V, Delbue S, Misiano P, et al. Phagocytosis and activation of bone marrow-derived macrophages by Plasmodium falciparum gametocytes. Malar J. 2021;20:81.

19. Bansal GP, Weinstein CS, Kumar N. Insight into phagocytosis of mature sexual (gametocyte) stages of Plasmodium falciparum using a human monocyte cell line. Acta Trop. 2016;157:96-101.

20. Joice R, Nilsson SK, Montgomery J, Dankwa S, Egan E, Morahan B, et al. Plasmodium falciparum transmission stages accumulate in the human bone marrow. Sci Transl Med. 2014;6:244re5.

21. Chua CLL, Brown G, Hamilton JA, Rogerson S, Boeuf P. Monocytes and macrophages in malaria: protection or pathology? Trends Parasitol. 2013:29:26-34.
22. Portugal S, Moebius J, Skinner J, Doumbo S, Doumtabe D, Kone Y, et al. Exposure-dependent control of malaria-induced inflammation in children. PLoS Pathog. 2014;10:e1004079.

23. Barfod L, Dalgaard MB, Pleman ST, Ofori MF, Pleass RJ, Hviid L. Evasion of immunity to Plasmodium falciparum malaria by lgM masking of protective IgG epitopes in infected erythrocyte surface-exposed PfEMP1. Proc Natl Acad Sci USA. 2011;108:12485-90.

24. Chaudhury S, Regules JA, Darko CA, Dutta S, Wallqvist A, Waters NC, et al. Delayed fractional dose regimen of the RTS, S/AS01 malaria vaccine candidate enhances an lgG4 response that inhibits serum opsonophagocytosis. Sci Rep. 2017;7:7998.

25. Daigneault M, Preston JA, Marriott HM, Whyte MKB, Dockrell DH. The identification of markers of macrophage differentiation in PMAstimulated THP-1 cells and monocyte-derived macrophages. PLOS ONE. 2010;5:e8668

26. Hill DL, Eriksson EM, Li Wai Suen CSN, Chiu CY, Ryg-Cornejo V, Robinson $L$, et al. Opsonising antibodies to P. falciparum merozoites associated with immunity to clinical malaria. PLoS ONE. 2013;8:e74627.

27. Chaudhury S, Ockenhouse CF, Regules JA, Dutta S, Wallqvist A, Jongert $E$, et al. The biological function of antibodies induced by the RTS, S/ AS01 malaria vaccine candidate is determined by their fine specificity. Malar J. 2016:15:301.

28. White MT, Bejon P, Olotu A, Griffin JT, Riley EM, Kester KE, et al. The relationship between $R T S$, S vaccine-induced antibodies, CD4+ T cell responses and protection against Plasmodium falciparum infection. PLOS ONE. 2013:8:e61395.

29. Chan J-A, Boyle MJ, Moore KA, Reiling L, Lin Z, Hasang W, et al. Antibody targets on the surface of Plasmodium falciparum-infected erythrocytes that are associated with immunity to severe malaria in young children. J Infect Dis. 2019;219:819-28.

30. Chandrasiri UP, Fowkes FJI, Beeson JG, Richards JS, Kamiza S, Maleta K, et al. Association between malaria immunity and pregnancy outcomes among Malawian pregnant women receiving nutrient supplementation. Malar J. 2016;15:547.

31. Jafarshad A, Dziegiel MH, Lundquist R, Nielsen LK, Singh S, Druilhe PL. A novel antibody-dependent cellular cytotoxicity mechanism involved in defense against malaria requires costimulation of monocytes Fc RII and FC RIII. J Immunol. 2007;178:3099-106.

32. Tebo AE, Kremsner PG, Luty AJF. Plasmodium falciparum: a major role for IgG3 in antibody-dependent monocyte-mediated cellular inhibition of parasite growth in vitro. Exp Parasitol. 2001;98:20-8.

33. Chiu CYH, Hodder AN, Lin CS, Hill DL, Li Wai Suen CSN, Schofield L, et al. Antibodies to the Plasmodium falciparum proteins MSPDBL1 and MSPDBL2 opsonize merozoites, inhibit parasite growth, and predict protection from clinical malaria. J Infect Dis. 2015;212:406-15.

34. Kana IH, Adu B, Tiendrebeogo RW, Singh SK, Dodoo D, Theisen M. Naturally acquired antibodies target the glutamate-rich protein on intact merozoites and predict protection against febrile malaria. J Infect Dis. 2017:215:623-30.

35. Kana IH, Singh SK, Garcia-Senosiain A, Dodoo D, Singh S, Adu B, et al. Breadth of functional antibodies is associated with Plasmodium falciparum merozoite phagocytosis and protection against febrile malaria. J Infect Dis. 2019:220:275-84.

36. Hviid $L$, Jensen ATR. PfEMP1 — a parasite protein family of key importance in Plasmodium falciparum malaria immunity and pathogenesis. Adv Parasitol. 2015;88:51-84.

37. Lambert LH, Bullock JL, Cook ST, Miura K, Garboczi DN, Diakite M, et al. Antigen reversal identifies targets of opsonizing lgGs against pregnancy-associated malaria. Infect Immun. 2014;82:4842-53.

38. Loughland JR, Woodberry T, Field M, Andrew DW, SheelaNair A, Dooley $\mathrm{NL}$, et al. Transcriptional profiling and immunophenotyping show sustained activation of blood monocytes in subpatent Plasmodium falciparum infection. Clin Transl Immunol. 2020;9:e1144.

39. Ogonda LA, Orago ASS, Otieno MF, Adhiambo C, Otieno W, Stoute JA. The levels of CD16/Fc gamma receptor IIIA on CD14+ CD16+ monocytes are higher in children with severe Plasmodium falciparum anemia than in children with cerebral or uncomplicated malaria. Infect Immun. 2010:78:2173-81.

40. Teirlinck AC, Roestenberg M, Bijker EM, Hoffman SL, Sauerwein RW, Scholzen A. Plasmodium falciparum infection of human volunteers 
activates monocytes and CD16+ dendritic cells and induces upregulation of CD16 and CD1c expression. Infect Immun. 2015;83:3732-9.

41. Tamm A, Schmidt RE. IgG binding sites on human Fcy receptors. Int Rev Immunol. 1997;16:57-85.

42. Antonelli LRV, Leoratti FMS, Costa PAC, Rocha BC, Diniz SQ, Tada MS, et al. The CD14+CD16+ inflammatory monocyte subset displays increased mitochondrial activity and effector function during acute Plasmodium vivax malaria. PLoS Pathog. 2014;10:e1004393.

43. Erdman LK, Cosio G, Helmers AJ, Gowda DC, Grinstein S, Kain KC. CD36 and TLR interactions in inflammation and phagocytosis: implications for malaria. J Immunol. 2009;183:6452-9.

44. Royo J, Rahabi M, Kamaliddin C, Ezinmegnon S, Olagnier D, Authier $\mathrm{H}$, et al. Changes in monocyte subsets are associated with clinical outcomes in severe malarial anaemia and cerebral malaria. Sci Rep. 2019;9:17545.

45. McGilvray ID, Serghides L, Kapus A, Rotstein OD, Kain KC. Nonopsonic monocyte/macrophage phagocytosis of Plasmodium falciparumparasitized erythrocytes: a role for CD36 in malarial clearance. Blood. 2000;96:3231-40.

46. Prato M, Gallo V, Giribaldi G, Arese P. Phagocytosis of haemozoin (malarial pigment) enhances metalloproteinase-9 activity in human adherent monocytes: role of IL-1 beta and 15-HETE. Malar J. 2008;7:157.

47. Parroche P, Lauw FN, Goutagny N, Latz E, Monks BG, Visintin A, et al. Malaria hemozoin is immunologically inert but radically enhances innate responses by presenting malaria DNA to Toll-like receptor 9. Proc Natl Acad Sci USA. 2007;104:1919-24.

48. Sisquella $X$, Ofir-Birin Y, Pimentel MA, Cheng L, Abou Karam P, Sampaio $\mathrm{NG}$, et al. Malaria parasite DNA-harbouring vesicles activate cytosolic immune sensors. Nat Commun. 2017;8:1985.

49. Mills CD. M1 and M2 macrophages: oracles of health and disease. Crit Rev Immunol. 2012:32:463-88

50. Chávez-Galán L, Olleros ML, Vesin D, Garcia I. Much more than M1 and M2 macrophages, there are also CD169(+) and TCR(+) macrophages. Front Immunol. 2015;6:263.

51. Klinkhamhom A, Glaharn S, Srisook C, Ampawong S, Krudsood S, Ward SA, et al. M1 macrophage features in severe Plasmodium falciparum malaria patients with pulmonary oedema. Malar J. 2020;19:182.

52. Gupta P, Lai SM, Sheng J, Tetlak P, Balachander A, Claser C, et al. Tissue-resident CD169+ macrophages form a crucial front line against Plasmodium infection. Cell Rep. 2016;16:1749-61.

53. Oakley MS, Chorazeczewski JK, Aleshnick M, Anantharaman V, Majam $\checkmark$, Chawla B, et al. TCRß-expressing macrophages induced by a pathogenic murine malaria correlate with parasite burden and enhanced phagocytic activity. PLoS ONE. 2018;13:e0201043.

54. Beham AW, Puellmann K, Laird R, Fuchs T, Streich R, Breysach C, et al. A TNF-regulated recombinatorial macrophage immune receptor implicated in granuloma formation in tuberculosis. PLoS Pathog. 2011;7:e1002375.

55. Hou N, Jiang N, Zou Y, Piao X, Liu S, Li S, et al. Down-regulation of Tim-3 in monocytes and macrophages in Plasmodium infection and its association with parasite clearance. Front Microbiol. 2017;8:1431.

56. Cha S-J, Park K, Srinivasan P, Schindler CW, van Rooijen N, Stins M, et al. CD68 acts as a major gateway for malaria sporozoite liver infection. J Exp Med. 2015;212:1391-403.

57. Gonçalves LA, Rodrigues-Duarte L, Rodo J, De Moraes LV, Marques I, Penha-Gonçalves C. TREM2 governs Kupffer cell activation and explains belr1 genetic resistance to malaria liver stage infection. Proc Natl Acad Sci USA. 2013;110:19531-6.

58. Kober DL, Brett TJ. TREM2-ligand interactions in health and disease. $J$ Mol Biol. 2017:429:1607-29.

59. Oldenborg P-A, Zheleznyak A, Fang Y-F, Lagenaur CF, Gresham HD, Lindberg FP. Role of CD47 as a marker of self on red blood cells. Science. 2000;288:2051-4.

60. Kurotaki D, Kon S, Bae K, Ito K, Matsui Y, Nakayama Y, et al. CSF1-dependent red pulp macrophages regulate CD4 T Cell responses. J Immunol. 2011;186:2229-37.

61. Nagelkerke SQ, Bruggeman CW, Den Haan JMM, Mul EPJ, Van Den Berg TK, Van Bruggen R, et al. Red pulp macrophages in the human spleen are a distinct cell population with a unique expression of Fc-g receptors. Blood Adv. 2018;2:941-63.
62. Zhou J, Ludlow LE, Hasang W, Rogerson SJ, Jaworowski A. Opsonization of malaria-infected erythrocytes activates the inflammasome and enhances inflammatory cytokine secretion by human macrophages. Malar J. 2012;11:343.

63. Terkawi MA, Takano R, Furukawa A, Murakoshi F, Kato K. Involvement of $\beta$-defensin 130 (DEFB130) in the macrophage microbicidal mechanisms for killing Plasmodium falciparum. Sci Rep. 2017;7:41772.

64. Kalantari P, DeOliveira RB, Chan J, Corbett Y, Rathinam V, Stutz A, et al. Dual engagement of the NLRP3 and AIM2 inflammasomes by Plasmodium-derived hemozoin and DNA during malaria. Cell Rep. 2014;6:196-210.

65. Coban C, Ishii KJ, Kawai T, Hemmi H, Sato S, Uematsu S, et al. Toll-like receptor 9 mediates innate immune activation by the malaria pigment hemozoin. J Exp Med. 2005;201:19-25.

66. Ioannidis LI, Nie CQ, Ly A, Ryg-Cornejo V, Chiu CY, Hansen DS. Monocyte- and neutrophil-derived CXCL10 impairs efficient control of blood-stage malaria infection and promotes severe disease. J Immunol. 2016;196:1227-38.

67. Shrivastava SK, Dalko E, Delcroix-Genete D, Herbert F, Cazenave PA, Pied S. Uptake of parasite-derived vesicles by astrocytes and microglial phagocytosis of infected erythrocytes may drive neuroinflammation in cerebral malaria. Glia. 2017;65:75-92.

68. Wilson NO, Jain V, Roberts CE, Lucchi N, Joel PK, Singh MP, et al. CXCL4 and CXCL10 predict risk of fatal cerebral malaria. Dis Markers. 2011;30:39-49.

69. Ioannidis $\sqcup$, Eriksson E, Hansen DS. CD14+ monocytes are the main leucocytic sources of CXCL10 in response to Plasmodium falciparum. Parasitology. 2020;147:465-70.

70. Mbagwu SI, Lannes N, Walch M, Filgueira L, Mantel P-Y. Human microglia respond to malaria-induced extracellular vesicles. Pathogens. 2019;9:21.

71. Couper KN, Barnes T, Hafalla JCR, Combes V, Ryffel B, Secher T, et al. Parasite-derived plasma microparticles contribute significantly to malaria infection-induced inflammation through potent macrophage stimulation. PLoS Pathog. 2010;6:e1000744.

72. Wang Y, Jönsson F. Expression, role, and regulation of neutrophil Fcy receptors. Front Immunol. 2019;10:1958.

73. Deniset JF, Kubes P. Neutrophil heterogeneity: bona fide subsets or polarization states? J Leukoc Biol. 2018;103:829-38.

74. Miralda I, Uriarte SM, McLeish KR. Multiple phenotypic changes define neutrophil priming. Front Cell Infect Microbiol. 2017;7:217.

75. Lima-Junior JDC, Rodrigues-da-Silva RN, Pereira VA, Storer FL, Perce-da-Silva DDS, Fabrino DL, et al. Cells and mediators of inflammation (C-reactive protein, nitric oxide, platelets and neutrophils) in the acute and convalescent phases of uncomplicated Plasmodium vivax and Plasmodium falciparum infection. Mem Inst Oswaldo Cruz. 2012;107:1035-41.

76. Rocha BC, Marques PE, de Souza Leoratti FM, Junqueira C, Pereira DB, do Valle Antonelli $L R$, et al. Type I Interferon transcriptional signature in neutrophils and low-density granulocytes are associated with tissue damage in malaria. Cell Rep. 2015;13:2829-41.

77. Rankin SM. The bone marrow: a site of neutrophil clearance. J Leukoc Biol. 2010;88:241-51.

78. Hellebrekers P, Hietbrink F, Vrisekoop N, Leenen LPH, Koenderman L. Neutrophil functional heterogeneity: identification of competitive phagocytosis. Front Immunol. 2017:8:1498.

79. Chorazeczewski JK, Aleshnick M, Majam V, Okoth WA, Kurapova R, Akue $A$, et al. TCR $\beta$ combinatorial immunoreceptor expression by neutrophils correlates with parasite burden and enhanced phagocytosis during a Plasmodium berghei ANKA malaria infection. Infect Immun. 2018;86:e00899-17.

80. Puellmann K, Kaminski WE, Vogel M, Nebe CT, Schroeder J, Wolf H, et al. A variable immunoreceptor in a subpopulation of human neutrophils. Proc Natl Acad Sci USA. 2006:103:14441-6.

81. Denny MF, Yalavarthi S, Zhao W, Thacker SG, Anderson M, Sandy AR, et al. A distinct subset of proinflammatory neutrophils isolated from patients with systemic lupus erythematosus induces vascular damage and synthesizes type I IFNs. J Immunol. 2010;184:3284-97.

82. de Leoratti FMS, Trevelin SC, Cunha FQ, Rocha BC, Costa PAC, Gravina $\mathrm{HD}$, et al. Neutrophil paralysis in Plasmodium vivax malaria. PLoS Negl Trop Dis. 2012;6:e1710. 
83. Mbengue B, Fall MM, Varela M-L, Loucoubar C, Joos C, Fall B, et al. Analysis of antibody responses to selected Plasmodium falciparum merozoite surface antigens in mild and cerebral malaria and associations with clinical outcomes. Clin Exp Immunol. 2019;196:86-96.

84. Joos C, Marrama L, Polson HEJ, Corre S, Diatta A-M, Diouf B, et al. Clinical protection from falciparum malaria correlates with neutrophil respiratory bursts induced by merozoites opsonized with human serum antibodies. PLoS ONE. 2010;5:e9871.

85. Dasari P, Reiss K, Lingelbach K, Baumeister S, Lucius R, Udomsangpetch $R$, et al. Digestive vacuoles of Plasmodium falciparum are selectively phagocytosed by and impair killing function of polymorphonuclear leukocytes. Blood. 2011;118:4946-56.

86. Kapelski S, Klockenbring T, Fischer R, Barth S, Fendel R. Assessment of the neutrophilic antibody-dependent respiratory burst (ADRB) response to Plasmodium falciparum. J Leukoc Biol. 2014;96:1131-42.

87. Terkawi MA, Takano R, Kato K. Differential gene expression profile of human neutrophils cultured with Plasmodium falciparum-parasitized erythrocytes. J Immunol Res. 2018;2018:6709424.

88. Boeltz S, Muñoz LE, Fuchs TA, Herrmann M. Neutrophil extracelIular traps open the Pandora's box in severe malaria. Front Immunol. 2017;8:874

89. Knackstedt SL, Georgiadou A, Apel F, Abu-Abed U, Moxon CA, Cunnington AJ, et al. Neutrophil extracellular traps drive inflammatory pathogenesis in malaria. Sci Immunol. 2019;4:eaaw0336.

90. Sil P, Hayes CP, Reaves BJ, Breen P, Quinn S, Sokolove J, et al. P2Y6 Receptor antagonist MRS2578 inhibits neutrophil activation and aggregated neutrophil extracellular trap formation induced by gout-associated monosodium urate crystals. J Immunol. 2017;198:428-42.

91. Lautenschlager SDOS, Kim T, Bidóia DL, Nakamura CV, Anders H-J, Steiger S. Plasma proteins and platelets modulate neutrophil clearance of malaria-related hemozoin crystals. Cells. 2019;9:93.

92. Lyke KE, Diallo DA, Dicko A, Kone A, Coulibaly D, Guindo A, et al. Association of intraleukocytic Plasmodium falciparum malaria pigment with disease severity, clinical manifestations, and prognosis in severe malaria. Am J Trop Med Hyg. 2003;69:253-9.

93. Mujuzi G, Magambo B, Okech B, Egwang TG. Pigmented monocytes are negative correlates of protection against severe and complicated malaria in Ugandan children. Am J Trop Med Hyg. 2006;74:724-9.

94. Banerjee R, Khandelwal S, Kozakai Y, Sahu B, Kumar S. CD47 regulates the phagocytic clearance and replication of the Plasmodium yoelii malaria parasite. Proc Natl Acad Sci USA. 2015;112:3062-7.

95. Oyong DA, Kenangalem E, Poespoprodjo JR, Beeson JG, Anstey NM, Price RN, et al. Loss of complement regulatory proteins on uninfected erythrocytes in vivax and falciparum malaria anemia. JCI Insight. 2018;3:e124854.

96. Rosa TFA, Flammersfeld A, Ngwa CJ, Kiesow M, Fischer R, Zipfel PF et al. The Plasmodium falciparum blood stages acquire factor $\mathrm{H}$ family proteins to evade destruction by human complement. Cell Microbiol. 2016;18:573-90.

97. Kennedy AT, Schmidt CQ, Thompson JK, Weiss GE, Taechalertpaisarn T, Gilson PR, et al. Recruitment of factor $\mathrm{H}$ as a novel complement evasion strategy for blood-stage Plasmodium falciparum infection. J Immunol. 2016;196:1239-48.

98. Serghides L, Patel SN, Ayi K, Kain KC. Placental chondroitin sulfate abinding malarial isolates evade innate phagocytic clearance. J Infect Dis. 2006;194:133-9.

99. Fernandez-Arias C, Lopez JP, Hernandez-Perez JN, Bautista-Ojeda MD, Branch O, Rodriguez A. Malaria inhibits surface expression of complement receptor 1 in monocytes/macrophages, causing decreased immune complex internalization. J Immunol. 2013;190:3363-72.

100. Lee WC, Russell B, Sobota RM, Ghaffar K, Howland SW, Wong ZX, et al. Plasmodium-infected erythrocytes induce secretion of IGFBP7 to form type II rosettes and escape phagocytosis. Elife. 2020;9:e51546.

101. Albrecht L, Lopes SCP, da Silva ABIE, Barbosa V, Almeida RP, Siqueira AM, et al. Rosettes integrity protects Plasmodium vivax of being phagocytized. Sci Rep. 2020;10:16706.

102. Klotz C, Frevert U. Plasmodium yoelii sporozoites modulate cytokine profile and induce apoptosis in murine Kupffer cells. Int J Parasitol. 2008;38:1639-50
103. Waddell SJ, Popper SJ, Rubins KH, Griffiths MJ, Brown PO, Levin M, et al. Dissecting interferon-induced transcriptional programs in human peripheral blood cells. PLoS ONE. 2010;5:e9753.

104. D'Ombrain MC, Robinson LJ, Stanisic DI, Taraika J, Bernard N, Michon $P$, et al. Association of early interferon- $\gamma$ production with immunity to clinical malaria: a longitudinal study among Papua New Guinean children. Clin Infect Dis. 2008;47:1380-7.

105. Su Z, Fortin A, Gros P, Stevenson MM. Opsonin-independent phagocytosis: an effector mechanism against acute blood-stage Plasmodium chabaudi AS infection. J Infect Dis. 2002;186:1321-9.

106. Williams TN, Wambua S, Uyoga S, Macharia A, Mwacharo JK, Newton CRJC, et al. Both heterozygous and homozygous a+ thalassemias protect against severe and fatal Plasmodium falciparum malaria on the coast of Kenya. Blood. 2005;106:368-71.

107. Williams TN, Mwangi TW, Wambua S, Alexander ND, Kortok M, Snow RW, et al. Sickle cell trait and the risk of Plasmodium falciparum malaria and other childhood diseases. J Infect Dis. 2005;192:178-86.

108. Uyoga S, Ndila CM, Macharia AW, Nyutu G, Shah S, Peshu N, et al. Glucose-6-phosphate dehydrogenase deficiency and the risk of malaria and other diseases in children in Kenya: a case-control and a cohort study. Lancet Haematol. 2015;2:e437-44.

109. Ayi K, Turrini F, Piga A, Arese P. Enhanced phagocytosis of ring-parasitized mutant erythrocytes: a common mechanism that may explain protection against falciparum malaria in sickle trait and beta-thalassemia trait. Blood. 2004;104:3364-71.

110. Cappadoro M, Giribaldi G, O'Brien E, Turrini F, Mannu F, Ulliers D, et al. Early phagocytosis of glucose-6-phosphate dehydrogenase (G6PD)deficient erythrocytes parasitized by Plasmodium falciparum may explain malaria protection in G6PD deficiency. Blood. 1998;92:2527-34.

111. Cao H, Wassall HJ, Forrester MA, Hall LS, Wilson HM, Shepherd J, et al. Hemoglobin $\mathrm{S}$ induces exposure of red blood cell membrane skeleton microdomains bearing mannose that stimulate phagocytosis by macrophages: a molecular basis for hemolysis in sickle cell disease but protection against Plasmodium falciparum malaria. Blood. 2018;132:3642.

112. Wolofsky KT, Ayi K, Branch DR, Hult AK, Olsson ML, Liles WC, et al. ABO blood groups influence macrophage-mediated phagocytosis of Plasmodium falciparum-infected erythrocytes. PLoS Pathog. 2012:8:e1002942.

113. Ataíde R, Mwapasa V, Molyneux ME, Meshnick SR, Rogerson SJ. Antibodies that induce phagocytosis of malaria infected erythrocytes: effect of HIV infection and correlation with clinical outcomes. PLoS ONE. 2011;6:e22491.

114. Hasang W, Dembo EG, Wijesinghe R, Molyneux ME, Kublin JG, Rogerson S. HIV-1 infection and antibodies to Plasmodium falciparum in adults. J Infect Dis. 2014;210:1407-14.

115. Ludlow LE, Zhou J, Tippett E, Cheng WJ, Hasang W, Rogerson SJ, et al. HIV-1 inhibits phagocytosis and inflammatory cytokine responses of human monocyte-derived macrophages to P. falciparum infected erythrocytes. PLoS ONE. 2012;7:e32102.

116. Kedzierska K, Ellery P, Mak J, Lewin SR, Crowe SM, Jaworowski A. HIV-1 down-modulates $\gamma$ signaling chain of FcyR in human macrophages: a possible mechanism for inhibition of phagocytosis. J Immunol. 2002;168:2895-903.

117. Shalmiev G, Krugliak M, Turrini F, Ginsburg H. Antimalarial drugs inhibit the phagocytosis of erythrocytes infected with Plasmodium falciparum. Trans R Soc Trop Med Hyg. 1996;90:558-62.

118. Cumming BM, Goldring JPD. Monocyte phagocytosis of malaria $\beta$-haematin in the presence of artemisinin, amodiaquine, chloroquine, doxycycline, primaquine, pyrimethamine and quinine. Exp Parasitol. 2019;197:93-102.

119. Hodge S, Hodge G, Jersmann H, Matthews G, Ahern J, Holmes M, et al. Azithromycin improves macrophage phagocytic function and expression of mannose receptor in chronic obstructive pulmonary disease. Am J Respir Crit Care Med. 2008;178:139-48.

120. Mimche PN, Thompson E, Taramelli D, Vivas L. Curcumin enhances nonopsonic phagocytosis of Plasmodium falciparum through up-regulation of CD36 surface expression on monocytes/macrophages. J Antimicrob Chemother. 2012;67:1895-904.

121. Serghides L, Patel SN, Ayi K, Lu Z, Gowda DC, Liles WC, et al. Rosiglitazone modulates the innate immune response to Plasmodium 
falciparum infection and improves outcome in experimental cerebral malaria. J Infect Dis. 2009;199:1536-45.

122. Serghides $L$, Kain $K C$. Mechanism of protection induced by vitamin $A$ in falciparum malaria. Lancet. 2002;359:1404-6.

123. Wu X, Dayanand KK, Thylur RP, Norbury CC, Gowda DC. Small moleculebased inhibition of MEK $1 / 2$ proteins dampens inflammatory responses to malaria, reduces parasite load, and mitigates pathogenic outcomes. $J$ Biol Chem. 2017;292:13615-34.

124. Seixas E, Ramalho JS, Mota LJ, Barral DC, Seabra MC. Bacteria and protozoa differentially modulate the expression of Rab proteins. PLOS ONE. 2012; 7:e39858.

125. Seixas E, Escrevente C, Seabra MC, Barral DC. Rab GTPase regulation of bacteria and protozoa phagocytosis occurs through the modulation of phagocytic receptor surface expression. Sci Rep. 2018;8:12998.

126. Peterson KR, Cottam MA, Kennedy AJ, Hasty AH. Macrophagetargeted therapeutics for metabolic disease. Trends Pharmacol Sci. 2018;39:536-46

127. Wang Y, Smith W, Hao D, He B, Kong L. M1 and M2 macrophage polarization and potentially therapeutic naturally occurring compounds. Int Immunopharmacol. 2019:70:459-66.
128. Ting DSJ, Beuerman RW, Dua HS, Lakshminarayanan R, Mohammed I. Strategies in translating the therapeutic potentials of host defense peptides. Front Immunol. 2020;11:983.

129. Campbell Y, Fantacone ML, Gombart AF. Regulation of antimicrobia peptide gene expression by nutrients and by-products of microbial metabolism. Eur J Nutr. 2012;51:899-907.

130. Wan M, van der Does AM, Tang X, Lindbom L, Agerberth B, Haeggström JZ. Antimicrobial peptide LL-37 promotes bacterial phagocytosis by human macrophages. J Leukoc Biol. 2014:95:971-81.

131. Lishko VK, Moreno B, Podolnikova NP, Ugarova TP. Identification of human cathelicidin peptide LL-37 as a ligand for macrophage integrin aMß2 (Mac-1, CD11b/CD18) that promotes phagocytosis by opsonizing bacteria. Res Rep Biochem. 2016;6:39-55.

\section{Publisher's Note}

Springer Nature remains neutral with regard to jurisdictional claims in published maps and institutional affiliations.
Ready to submit your research? Choose BMC and benefit from:

- fast, convenient online submission

- thorough peer review by experienced researchers in your field

- rapid publication on acceptance

- support for research data, including large and complex data types

- gold Open Access which fosters wider collaboration and increased citations

- maximum visibility for your research: over 100M website views per year

At BMC, research is always in progress.

Learn more biomedcentral.com/submissions 